\author{
RUDOLF BRÁZDIL, PAVEL ZAHRADNÍČEK, PETR DOBROVOLNÝ, OLDŘICH \\ KOTYZA, HUBERT VALÁŠEK
}

\title{
HISTORICAL AND RECENT VITICULTURE AS A SOURCE OF CLIMATOLOGICAL KNOWLEDGE IN THE CZECH REPUBLIC
}

R. B rázdil, P. Z a hradníček, P. Dobrovolný, O. Kotyza, H . $\mathrm{V}$ a l á š e $\mathrm{k}$ : Historical and recent viticulture as a source of climatological knowledge in the Czech Republic. - Geografie-Sborník ČGS, 113, 4, pp. 351-371 (2008). - The cultivation of the vine (Vinis vinifera) that yields grapes for wine manufacture is strongly influenced by the weather. This relationship enables the use of historical viticultural data (e.g., the start date of the grape harvest, notes on wine quality and quantity) for the reconstruction of temperatures and weather extremes in past times. This paper summarises the basics of the relationship between viticulture and climate in the Czech Lands. We compile historical observations before $\mathrm{AD} 1500$ and for the 16th-18th centuries from various types of documentary evidence. The starting dates of the grape harvest in Znojmo for 1800-1890 are used for the reconstruction of April-August temperatures in Brno. The quality of the wine from Bzenec (1800-1890), Znojmo (1802-1845) and Bohutice (1861-1912) is analysed with respect to temperatures corresponding to excellent, good, average and bad wine. Times of flowering and grape harvest are compared with temperatures at the Velké Pavlovice station for the period 1956-2007 and 1984-2007, for various grape varieties.

KEY WORDS: vine - viticulture - vintage - grape harvest - wine quality - wine quantity - temperature reconstruction - weather extremes

The paper was prepared with financial support from the Grant Agency of the Czech Republic for project No. 521/08/1682.

\section{Introduction}

Cultivation of the vine Vinis vinifera in Europe, which originally came from latitudes $25-40^{\circ} \mathrm{N}$, was extended to the south and north as a secondary enterprise. Viticulture in the Czech Republic is strongly influenced by the fact that it is at the northernmost extent of its range in Europe (Koštál 1958). In such conditions, its dependence on weather patterns increases enormously (Kraus 1964, 1999). The nature of the impact of the weather is closely bound to the times of year in which the weather affects the vines' stages of development such as growth, flowering and fruiting (e.g. Winkler et al. 1974, Mullins 1992). Predominantly abundant sunshine and higher air temperatures, together with sufficient precipitation, are factors positively influencing yield and quality of grapes. On the other hand, cold and rainy weather in the period of maturation, extreme winter frosts, late spring and early autumn frosts and hailstorms appear as negative factors. The occurrence of various vine diseases and pests also depends to some extent upon meteorological patterns.

Such close association of vine cultivation with the weather means that information related to viticulture may supply direct or indirect knowledge 
about the weather and its representation. However, the difference between strictly natural information (such as flowering date and wine quality) and culturally influenced information (such as harvest date and wine quantity) has to be taken in account. This knowledge finds application in historical climatology, in which, by means of the analysis of various types of documentary evidence, the climate and the occurrence of hydrometeorological extremes may be reconstructed for the period prior to systematic instrumental meteorological observation (Brázdil et al. 2005a).

Among European papers dealing with documentary data on vine cultivation, the study made by Le Roy Ladurie and Baulant (1980) is worthy of particular mention. They collected 103 series of vintage data from eastern and central France, western Switzerland and south-west Germany for the period 1484-1879 that could be used for temperature reconstruction. Based on this data, Burkhardt and Hense (1985) reconstructed April-July temperatures for Basle in 1484-1768. Many other papers related to the climatological use of viticultural data have originated in Switzerland (Pfister 1981, 1988; Meier et al. 2007), Austria (Lauscher 1983, 1985; Strömmer 2003) and Germany (Lauer, Frankenberg 1986; Glaser 1991). Střeštík and Verő (2000) used measurements of the lengths of grapevine sprouts from Közseg (Hungary) for the reconstruction of spring temperatures after $\mathrm{AD}$ 1740. Data from north-eastern France and Switzerland have been used to check the paleoclimatological reconstruction of the North Atlantic Oscillation Index (Souriau, Yiou 2001). Chuine et al. (2004) published a reconstruction of April-August temperatures in Burgundy for $\mathrm{AD}$ 1370-2003 using a process-based phenology model developed for the Pinot Noir grape (see also Le Roy Ladurie 2004, 2006, 2007).

The vintage series published by Le Roy Ladurie and Baulant (1980) were used by Menzel (2005) to demonstrate the extremity of the 2003 heat-wave in Europe in the context of the past 500 years. April-August temperatures account for $84 \%$ of the year-by-year variability in the dates for grape harvesting in Western Europe. However, Keenan (2007), basing his analysis on a paper by Chuine et al. (2004) and concentrating on the statistical point of view, argued, in terms of the 2003 patterns, that "grape-derived temperature estimates are highly unreliable".

Climatological use of information on vine cultivation in the Czech Republic has not attracted any particular interest to date. For example, a summary paper by Frolec et al. (1973) devoted to viticulture in the Czech Republic paid only little attention to the topic of climate. The most important paper is by Pejml (1974). Using data for the area of Velké Žernoseky (No. 31 in Fig. 1) from 1816 to 1896 , he looked for relationships between temperatures in the vegetation period and yields of grapes and/or quality of wine. In the years with good or excellent wine, the probability of above-mean temperatures in the vegetation period achieved $73 \%$, while in the years with low quality the probability of below-mean temperatures was $77 \%$. A weaker relationship emerged between temperatures and yield. More recently, Brázdil and Valášek (2005) summarised data on vine cultivation in the Czech Republic in terms of the documentary evidence that may be used for historical climatology.

The current article is an attempt to make an inventory of recent knowledge concerning vine cultivation in the Czech Republic with respect to the study of climate variability over a period of several centuries. After a description of basic climate-related wine data and the sources from which they can be extracted, information related to viticulture is analyzed for individual centuries. Series of harvest dates and wine quality as temperature proxies are 


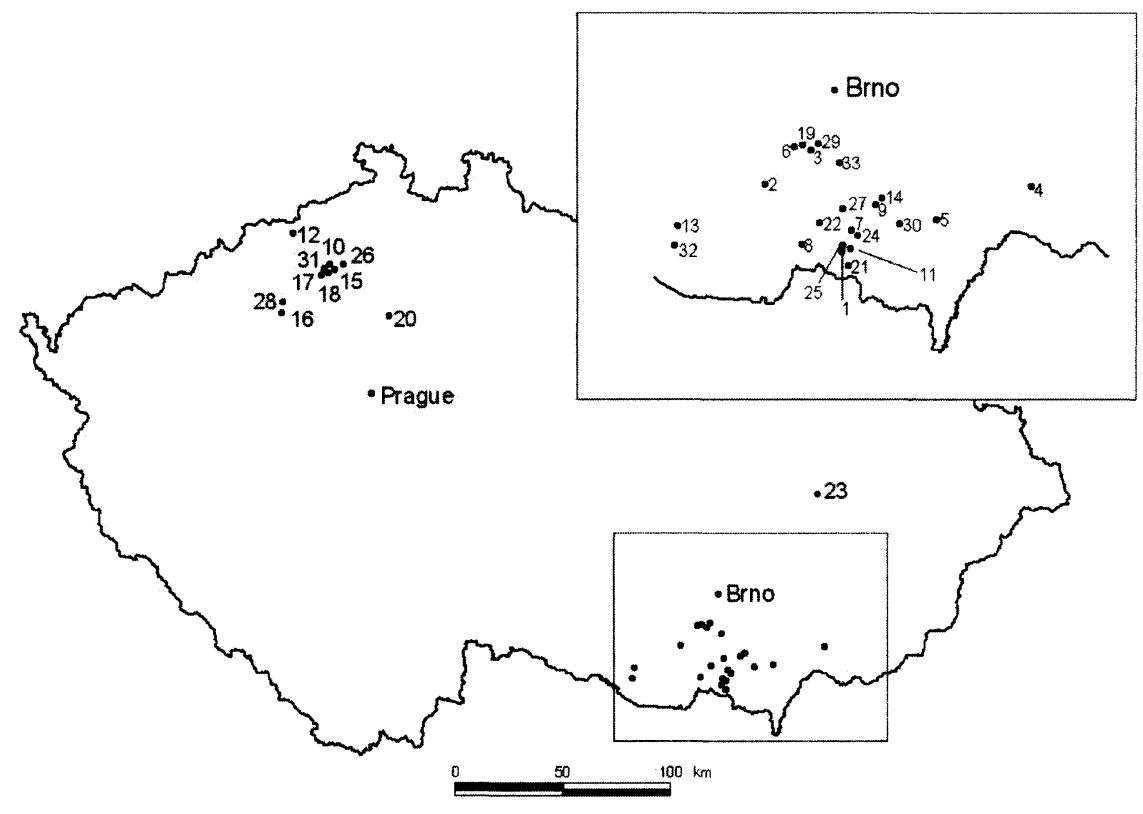

Fig. 1 - Location of places in the Czech Republic mentioned in the text: 1 - Bavory, 2 Bohutice, 3 - Bratčice, 4 - Bzenec, 5 - Čejkovice, 6 - Dolní Kounice, 7 - Dolní Věstonice, 8 - Drnholec, 9 - Hustopeče, 10 - Kamýk, 11 - Klentnice, 12 - Krupka, 13 - Kuchařovice, 14 - Kurdějov, 15 - Litoměřice, 16 - Louny, 17 - Lovosice, 18 - Malíč, 19 - Mělčany, 20 Mělník, 21 - Mikulov, 22 - Mušov, 23 - Olomouc, 24 - Pavlov, 25 - Perná, 26 - Ploskovice, 27 - Pouzdřany 28 - Raná, 29 - Syrovice, 30 - Velké Pavlovice, 31 - Velké Žernoseky, 32 - Znojmo, 33 - Židlochovice.

investigated for the 19th century. A reflection of temperature variability in more recent vine phenophases (1956-2007) is given (phenophases are significant, clearly observable and periodically appearing life stages of plants, such as flowering, ripening etc., which are connected with changes of weather patterns in the course of the year). Finally, the importance of the climate for past viticulture is discussed.

\section{Information on vines for the reconstruction of climate and weather extremes in the Czech Republic}

The following types of information may be interpreted climatologically:

(i) Start of the grape harvest (vintage): The time at which the grape harvest begins depends on the weather patterns in the months that precede it. Close relations exist between grape harvest and flowering dates (Chuine et al. 2004). Warm, sunny weather contributes to an early start, while colder, rainy weather slows down the ripening of the grapes. The timing of the vintage contains proxy information on temperature patterns in the foregoing period, so systematic records of it may be used for quantitative temperature reconstruction. However, the start of the grape harvest does not depend 
entirely upon the climate; commercial decisions made by winemakers and wine merchants also play a significant part. For example, they might leave the grapes to ripen further in the vineyards until late autumn in an attempt to enhance the quality of the resulting wine. While in some cases this has led to better grapes (e.g. in 1578 in the Litoměřice area), in other years the whole yield might have been destroyed by early frosts (e.g. in 1579, Kniha pamětní litoměřckých městských písařu). Furthermore, local traditions (for example, bans on vintage) and parochial festivities play an important role in the longterm scale.

(ii) Quality of wine: The quality of wine is often a reflection of the temperature and humidity patterns that precede the harvest. Grapes with a high sugar content in the must (the grape juice before or during fermentation) correspond with warmer and drier weather at the time of ripening and a "sweet" wine. On the other hand, low sugar content, a consequence of prevailing cold and rainy weather, leads to "dry", more astringent, or even sour wine.

(iii) Quantity of wine: A bad grape harvest and subsequent lower quantity of wine may be related to the occurrence of diseases and pests (e.g. in 1588 considerable quantities of grapes were eaten by flocks of birds (fieldfares) in the Litoměřice area - Kniha pamětní litoměrických městských písařủ), or to the negative impacts of meteorological extremes (e.g. a hard winter, late spring and early autumn frosts, hail, etc.).

Climatologically utilisable information comes from documentary evidence or phenological observations:

a) Documentary evidence

(i) Chronicles, annals, memoirs: Personal written records made by individuals or on behalf of religious and/or commercial concerns may contain information about the start of the harvest, damage to vineyards, quality, quantity and prices of wine. For example, the Kniha pamětní litoměřckých městských písařů of Litoměřice includes a great deal of viticultural data from 1570-1607. Similarly, the "Memory Book of Krupka" by master-tanner Michel Stüeler from 1629-1649 (Knott s.a.) cites quantity and quality of wine and damage to vineyards.

(ii) Systematic daily records: Information on vine cultivation is also reflected in the diaries of people who took systematic records that often contained incidental visual weather observations. Baron Peter Forgatsch wrote in his Brno records for 27 May 1812 that frosts in recent days had been very harmful to fruit trees and vineyards. Further, his entry for 5 September states that if the weather does not warm up, the grapes will not ripen. Eventually, there was a lot of rain, and thus a large quantity of grapes (entry for 30 September), but the quality of the wine is not mentioned (Welzl 1910).

(iii) Personal and official correspondence: This often includes information about the yield and quality of the grape harvest. For example, Zdeněk Lev of Rožmitál asked Martin Stř́težský of Drast, a burgrave in Ploskovice, to buy wine for him, in a letter from Prague dated 1 March 1526. He had heard that wine was cheap in Litoměřice (Dvorský 1888). This demonstrates a good yield from the previous year's harvest, something that is confirmed by other sources: an abundance of a good wine in $\mathbf{1 5 2 5}$ is mentioned by Daniel Adam of Veleslavín (Adam z Veleslavína 1590), a large yield of wine by Chronicon Magistri Georgii Pisensis (1907). Prince Otto, in a letter dated 18 October 1719 from Olomouc to his brother, Cardinal Wolfgang Hannibal, a prince of 


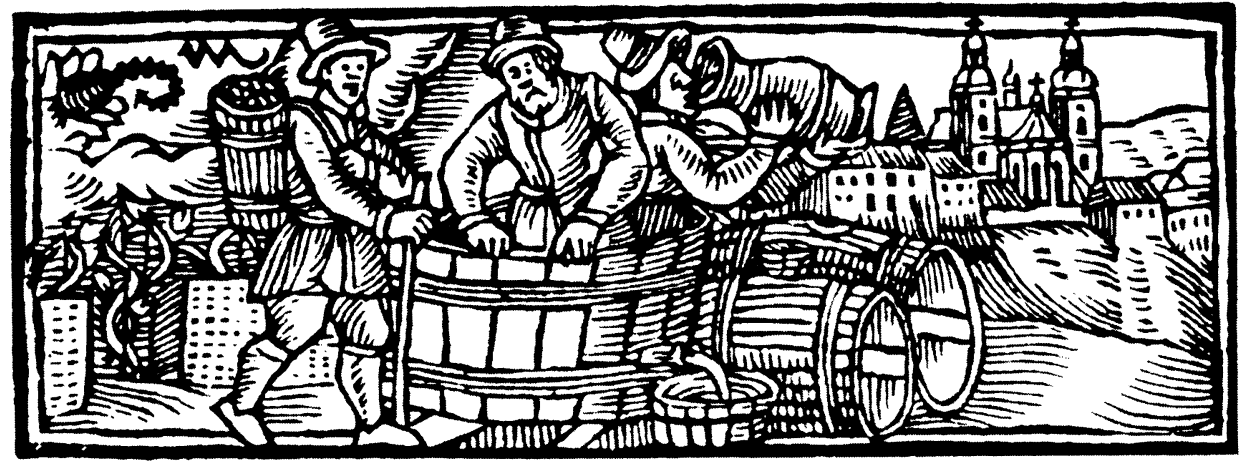

Fig. 2 - Symbols of vintage and grape-pressing were used to portray the month of October by Johann Willenberg in the calendar for 1604 . The vintage began most frequently in that month in Louny as well at other locations in the Czech Lands.

Schrattenbach, expressed pleasure at a good vintage, excellent wine and another good year for wine in Moravia (Lechner 1896).

(iv) Journalism: Newspapers often contain information about vintage or damage to vines. For example, according to the Brünner Zeitung of 30 September 1809, the harvest was already under way in Brno although it usually started on 6 October at the earliest. An above-average yield of grapes and high quality of wine was anticipated. Another report mentions that vines in Brno were blossoming for a second time after 12 September 1822, but that the vintage proper started on 26 September. The harvest began earlier than in the immediately previous years: $1819-4$ October, $1820-17$ October, 1821 - 24 October (Mährisch-Ständische Brünner Zeitung).

(v) Official financial records: These consist of evidence related to economic activity and the official record-keeping that accompanied it. For example, account books kept for the town of Louny, surviving for various time intervals in the 15th-17th centuries, feature wages paid every Saturday to harvesters (Fig. 2) or to other vineyard workers in the course of the year (e.g. for spreading manure, hoeing and other ground-work; Brázdil, Kotyza 2000). Because these wages reflected work done in the given weeks, interannual fluctuations in the timing of particular activities were consequences of weather patterns in the previous days or weeks. Farmers' requests for tax relief arising out of damage done to vineyards by extremes of weather (mainly hail and frost) for the Dietrichstein demesnes of Dolní Kounice and Mikulov from 1650-1849 are an important source in southern Moravia (Brázdil et al. 2003).

(vi) Technical papers: Climate-related viticultural data may also be extracted from a range of technical papers (e.g. Katzerowsky 1887; Donek et al. 1932). Koštál (1958) published grape yields for Malíč, Kamýk and Lovosice, covering various periods of the 16th-18th centuries, and mentioned the importance of meteorological factors to the value of yields. Such authors often worked with original archive sources, some of which may not have survived to this day. Many such studies were published, for example, in the journal Vinařský obzor (Viticultural horizon), founded in 1907.

b) Phenological observations

Phenological observations in the Czech Lands began in the 1780 s thanks to the work of Director Antonín Strnad at the Prague-Klementinum observatory 
and have continued since (Nekováŕ 2008). Phenological yearbooks started to be published from 1923 under the auspices of the Agriculture Research Institute of Brno and from 1938 under the Central Meteorological Institute (later Hydrometeorological Institute) in Prague (Miháliková 1983), but vine observations were not included in them. However, in the archives of the Czech Hydrometeorological Institute, viticultural data appear in original handwritten observations preserved from individual phenological stations. Systematic observations may be partly completed by data taken from various other documentary sources (as mentioned above) but their temporal and spatial distribution is discontinuous.

\section{Historical information on the vine as a climate indicator}

\subsection{Climate and viticulture before AD 1500}

Information on viticulture in the Czech Lands before $\mathrm{AD} 1500$ is sparse and limited mainly to wine quality and quantity (Brázdil, Kotyza 1995). The first report, from $\mathrm{AD} 1122$, mentions an ample yield of grapes. Further reports refer to damage to vineyards by late spring frosts $(1258,1283,1323,1331$, June $1424,1430,1448,1485,1486)$ and hail (1260), differing qualities of wine (good -1369 , very bad or sour $-1254,1259,1335,1487,1491$ ) as well as its quantity (good yield, plenty of wine - 1260, 1270, 1319, 1320, 1324, 1442, 1469, 1484, 1499 , small quantity or lack of wine $-1256,1262,1266,1310,1330,1333$, $1335,1337,1486,1487,1491)$. In 1420 , vineyards were already in blossom on 4 April after a mild winter. For 28 October 1335, only the start of the vintage is mentioned (for quotations of all sources, see Brázdil, Kotyza 1995).

For the 15th century, records of the Louny "Liber rationum" (Vaniš 1979) mention the start of grape harvest for the weeks before 8 November 1451 (the latest of the given dates), 23 October 1452, 29 October 1453, 28 October 1454, 13 October 1455, 1 November 1456, 3 October 1457, 9 October 1458, 22 October 1459, 20 October 1460, 18 October 1462, 17 October 1463, 16 October 1469, 29 October 1470 and 30 September 1471 (the earliest of the given dates).

\subsection{Climate and viticulture in the $16 \mathrm{th}-19 \mathrm{th}$ centuries}

Decadal frequencies of weather extremes with documented damage to vineyards (late spring and early autumn frosts, hail), of wine quality (excellent, good, average and bad) and wine quantity (abundant, average, low) have been calculated (Fig. 3) separately for the two key viticulture regions of the Czech Republic (the Litoměřice and Louny areas in Bohemia and southern Moravia). Despite incomplete annual evidence on the vines, the data sources described in the previous chapter, and those that follow, were used for this.

\subsubsection{The 16th century}

The greater part of viticultural data for the 16th century comes from the account books for Louny and its estates (Brázdil, Kotyza 2000) and from the Kniha pamětní litoměřických městských pisařu for Litoměřice. Only little data is available for Moravia, mainly from the administrator of the Žerotín estate 


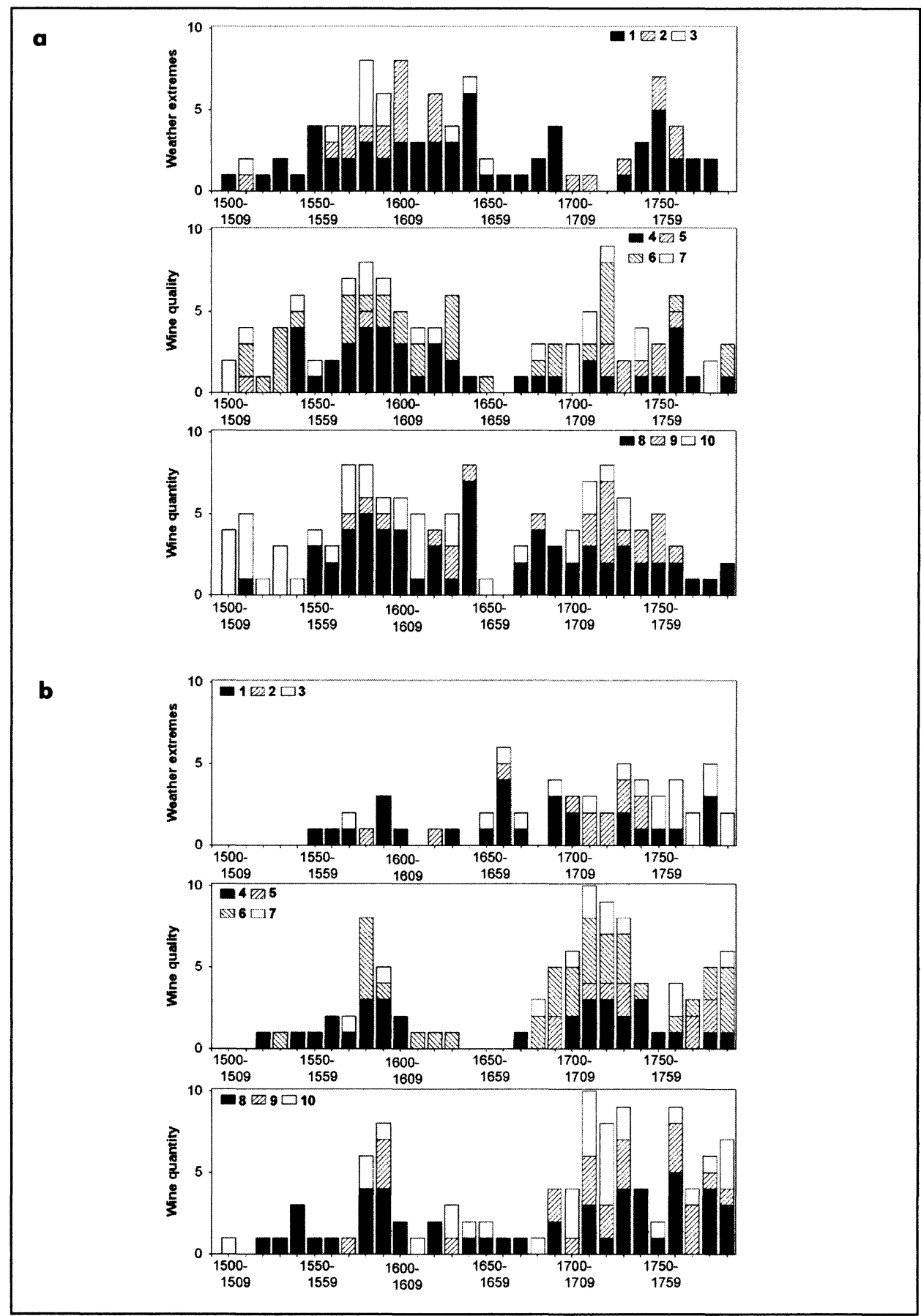

Fig. 3 - Decadal frequencies of weather extremes damaging vines ( 1 - late spring frost, 2 early autumn frost, 3 - hail), wine quality (4 - bad, 5 - average, 6 - good, 7 - excellent) and wine quantity ( 8 - low, 9 - average, 10 - abundant) in viticultural regions of Bohemia (a) and Moravia (b) in the 16th-18th centuries. 
in Židlochovice, Matyáš Matuška from Topolčany (Ondrůj 1977). Otherwise, there are many years for which no information related to viticulture is available.

Looking at the frequency of various aspects of viticulture in Bohemia, several decades stand out (Fig. 3a). The start of the grape harvest was recorded for only 19 years of the 16th century. In terms of wine quality, four years with good wine in the 1530 s and four years with sour wine in the 1540 s, 1580 s and 1590 s should be mentioned. Small quantities of wine were recorded in the 1580 s (for five years) followed by the 1570 s and 1590 s (four years). The $1500 \mathrm{~s}-1510 \mathrm{~s}$ and 1530 s proved more favourable from this point of view, with abundant harvests and no year of sour wine. Damage by late spring frosts occurred in four years of the 1550s and hail did damage in the 1580s with the same frequency. In southern Moravia, the 1580s-1590s were remarkable for their frequency of low yields (four years each) and sour wine (three years), but also for five years with good wine in the 1580s (Fig. $3 \mathrm{~b}$ ).

The foregoing information about viticulture in the Czech Lands relates well to the known summer climate development in Central Europe during the 16th century, with its cooler and wetter deterioration after 1560 (Pfister, Brázdil 1999). On the other hand, the exceptionally warm and dry year of 1540 was remarkable for an excellent wine, remembered in Central Europe for several centuries to come (Glaser et al. 1999).

\subsubsection{The 17th century}

Rich viticulture data are available for the first three decades of the 17th century thanks to the Louny account books, particularly their "Registers of Incomes and Expenditures" and "Registers of Raná Farm" (Brázdil, Kotyza 2000 ). For example, the times at which the harvest started are available for 22 years in the 1600-1632 period. The earliest harvest was recorded on 8 September 1616, after a very warm and dry summer, by Louny chronicler Pavel Mikšovic (the week preceding 24 September on Raná Farm). On the other hand, the latest recorded dates were in the weeks before 15 November 1608 and 16 November 1619 (Brázdil, Kotyza 2000). Increased damage to vineyards by spring and autumn frosts in the 1600 s and 1620 s is worthy of note (Fig. 3a). While in 1614 the production of beer in Litomerrice came to a halt because of a glut of wine (Donek et al. 1932), Pavel Mikšovic recorded in 1627 that no-one in Louny could remember such sour wine for 30 years (Brázdil, Kotyza 2000).

The following two decades of the 17th century may be characterised from the records of Michel Stüeler of Krupka (Knott s.a.). While the 1630s were characterised by good wine in four years, the 1640s were almost barren. May frosts damaged the vines every year in 1641-1645. Moreover, Stüeler mentions only a small quantity of wine for 1640, 1646-1647 and no wine at all for 1648-1649 (Brázdil et al. 2004) - a total of seven relatively barren years in the 1640 s.

Wine quality information in Moravia is absent for the $1640 \mathrm{~s}-1660 \mathrm{~s}$, but reports of frost damage appear again in the 1660s (Fig. 3b). Vineyards in many parts of southern Moravia were heavily damaged by frosts on 18 May 1662. On 5-6 September 1664, a heavy frost affected vineyards in the Mikulov area, with less damage to the vineyards of the aristocracy compared to those of their subjects. Frost damage to vineyards around various villages in southern Moravia is further mentioned for 7 May 1666, before 19 May 1667 and again on 2 May 1668. Moreover, hail heavily damaged vineyards in 
Mušov and Pouzdřany on 21 July 1664 (Brázdil et al. 2003).

Further data to the end of the 17th century are incomplete to a greater or lesser extent. In the last two decades the number of low grape yields increased in Bohemia (Fig. 3a). Despite some damage to vineyards by spring frosts in the $1690 \mathrm{~s}$, three years of good wine were recorded in southern Moravia (Fig. 3b).

\subsubsection{The 18th century}

For Moravia, information about yields of grapes, quality and prices of wine for 1704-1743 comes from a Jesuit of the Olomouc college, priest for the Čejkovice demesne (Hlavinka 1908). For several years of this period this can be supplemented by the "Memory Book" for Bzenec (Hanák 1922), the Kronika Hustopeči (Chronicle of Hustopeče) as well as chronicles relating to several other places in southern Moravia. Viticulture data from Bohemia is mainly derived from the records of Anton Gottfried Schmidt, a Litoměřice town clerk (Katzerowsky 1887).

The 1700 s-1730s and 1790 s may be considered the most fruitful decades for Moravia; wine both excellent and good was recorded in four-six of their years (Fig. 3b). But every decade in the 1700 s-1730s also threw up two or three years with sour wine. A similar situation occurred in Bohemia, where excellent wine occurred once and good wine five times in the $1720 \mathrm{~s}$, but only sour wine was available there in four years of the 1760s (Fig. 3a). Wine quantity in Moravia fluctuated between five years with abundant harvests in the 1720 s and five years with small harvests in the $1760 \mathrm{~s}$. The unpleasant 1760s correspond to records kept by Jan Josef Albrecht, a Mělník scribe, who mentioned bad yields in 1757-1765 (Teplý 1902). In Bohemia the harvest was average in five years of the $1720 \mathrm{~s}$.

As in previous centuries, many sources document damage to vineyards. For example, on 15 May 1712, hail damaged vineyards in the villages of Klentnice, Pavlov, Perná and the Drnholec demesne (Brázdil et al. 2003). During the $1750 \mathrm{~s}$, spring frost damage to vineyards was recorded in Bohemia for five years and autumn frost damage for two other years (Fig. 3a). On the night of 25/26 May 1796, hail totally or partially destroyed vineyards in Dolní Kounice, Mělčany, Syrovice and Bratčice (Brázdil et al. 2003).

\subsubsection{The 19th century}

Viticulture in the 19th century is better documented than that of previous centuries. A series of vintage beginnings exists for Znojmo, compiled from two sources:

- the protocols of the town council for the period 1800-1864 (Vinobranni, vinice a víno)

- announcements of the beginning of the vintage by the town council in the Znaimer Wochenblatt for the period 1865-1890.

Some years are missing from this series: 1801-1803, 1805-1806, $1809-1810,1851,1865-1866,1876$ and 1883 . This is due in particular to missed harvests in years of crop failure. For example, the yield was negligible in Bzenec and Znojmo in 1805, the wine was sour and poured away in front of the wine cellars. In 1866, the vines were totally frozen by heavy May frosts in several places (Haase 1873, Anonymous 1908). Altogether, the starting dates for harvests are available for a total of 76 years. 
Viticultural data from Znojmo were compared with the Brno temperature series, which is a homogeneous long-term series starting in 1799 (Brázdil et al. 2005b, Stěpánek et al. 2006). Brno temperatures are highly correlated with the recent Kuchařovice meteorological station, located close to Znojmo: 0.98 for April and May, and 0.97 from June to September (period 1961-2007). This means that Brno is sufficiently representative for this analysis.

To assess the potential of Znojmo vintage data for climate reconstruction, its relation to temperatures from the Brno series was studied using correlation coefficients between the two variables. The highest correlation was found for April-August (0.57), followed by May-July (0.56). Adding September or August temperatures to previous months does not have any significant influence on changes in the correlations. This is due to the decisive role played by late-spring temperatures, while August and September temperatures strongly influence the sugar content rather than the timing of the grape harvest (Chuine et al. 2004; see also Fig. 6). The strong relationship between the beginning of the grape harvest and April-August temperatures in the Znojmo region is in agreement with a similar study performed for Switzerland (Meier et al. 2007).

For application of the linear regression model, a calibration/verification exercise between Znojmo vintage data (predictor) and Brno temperatures (predictand) was performed, separating the whole period into two parts with 38 years always available (i.e. 1800-1847 and 1848-1890). Then the linear regression model was calculated for the first sub-period and the temperatures obtained were independently verified using data from the second period, and vice versa. The accuracy of the quantitative reconstruction, for both the calibration and the verification periods, was evaluated by squared correlation coefficient $\mathrm{r}^{2}$ (representing the variance explained by the statistical model), with reduction of error RE and coefficient of efficiency CE (Cook et al. 1994). Using these statistics, the reconstructed temperatures may be compared with those measured (Table 1).

The revealed April-August temperature variance of between $38 \%$ and $47 \%$ is comparable with that of April-September temperatures (36\%) reconstructed from tree rings in northern Bohemia (Brázdil et al. 1997). Although the subperiods used for the two calibrations/verifications are relatively short, positive values of $\mathrm{RE}$ and $\mathrm{CE}$ for both of them support the reliability of the linear regression model. Thus for the final reconstruction of April-August temperatures, the whole overlapping period 1800-1890 was used. The suitability of the regression model was further tested with Durbin-Watson statistics (DW). A value of DW $=1.44$ for one independent variable and for 38 years does not indicate significant positive autocorrelation in residuals and proves suitability for the linear regression model used. Temperature measurements from Brno have been expressed in the form of anomalies with respect to the 1961-1990 reference period. A 95\% confidence interval was also expressed for each reconstructed value (Fig. 4). The unexplained variance of the linear regression model may be attributed to other natural factors influencing vine growth, flowering and fruiting (such as other climate elements, pests, diseases, etc.) and human activities reflected in grape harvesting.

It follows from Figure 4 that there is a good correspondence between measured and reconstructed temperatures, especially from the 1830 s to the $1870 \mathrm{~s}$. There is also a lack of coherence in the $1880 \mathrm{~s}$. The largest differences between measured and reconstructed temperatures are related to the years with the most extreme April-August temperatures with respect to the 
Table 1 - Measures of reconstruction skill of Brno April-August temperatures. Vintage data from Znojmo are used as an independent variable in the model: $\mathrm{r}^{2}$ - squared correlation coefficient, $\mathrm{RE}$ - reduction of error, $\mathrm{CE}$ - coefficient of efficiency, MSE - mean square error.

\begin{tabular}{|l|c|c|c|}
\hline Characteristics & $1800-1847$ & $1848-1890$ & $1800-1890$ \\
\hline $\mathrm{r}^{2}$ & 0.382 & 0.468 & 0.329 \\
$\mathrm{RE}$ & 0.320 & 0.401 & 0.339 \\
$\mathrm{CE}$ & 0.351 & 0.353 & - \\
$\mathrm{MSE}$ & 0.533 & 0.307 & 0.428 \\
\hline
\end{tabular}
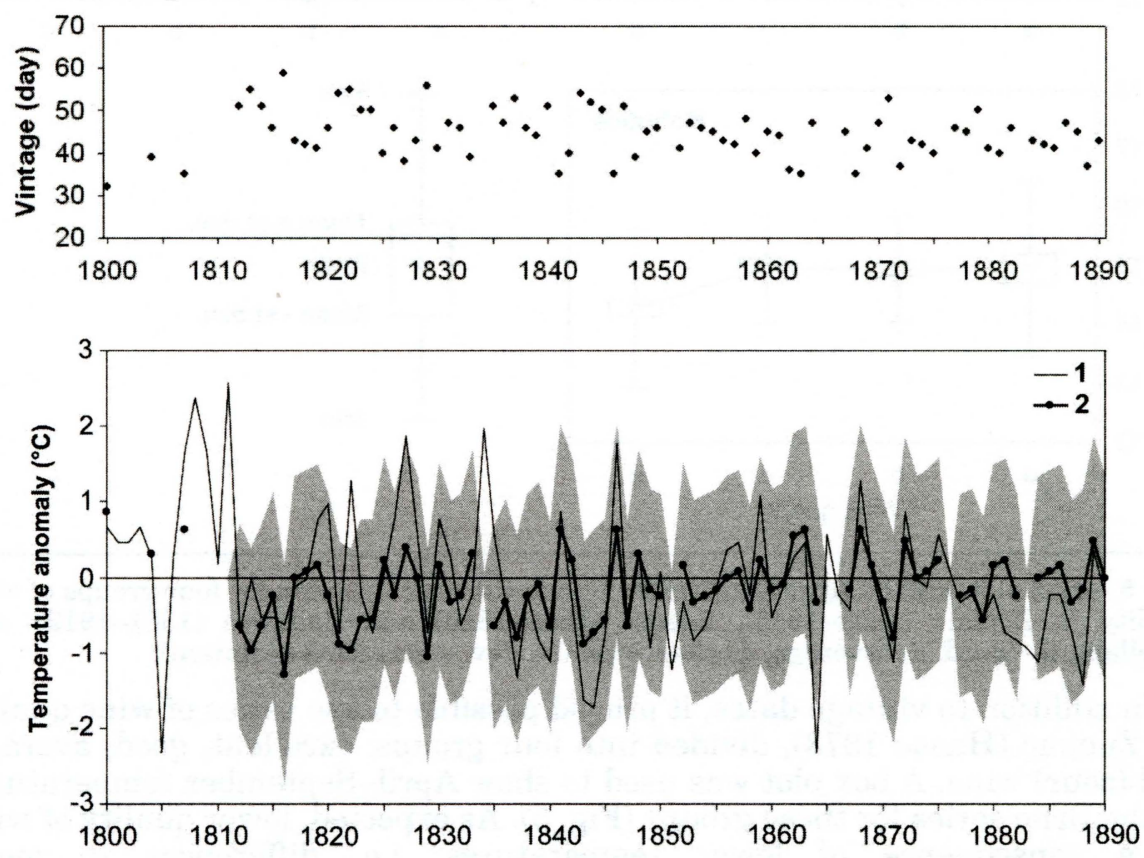

Fig. 4 - Variability of beginnings of vintage in Znojmo (number of days after 1 September) (above) and comparison of measured (1) and reconstructed (2) Brno April-August temperatures expressed as anomalies from the 1961-1990 reference period and reconstruction of uncertainty (shaded area) expressed as a $95 \%$ confidence interval for each reconstructed value in the period 1800-1890 (below).

reference period. Thus the variability of the reconstructed temperatures is suppressed to some extent, but this is a common feature of linear regressionbased models. Moreover, higher differences in some of the shorter sub-periods or in individual years can be attributed to the fact the beginning of vintage may be influenced by other factors. For instance, the latest beginning of vintage in the series processed is 1816 , often referred as "the year without a summer" as a result of the eruption of Tambora in 1815 (Písek, Brázdil 2006). Relatively higher differences appear between measured and reconstructed data in several years. For example, the harvest started significantly later in 1822 and 1827 (very good wine) and earlier in 1864 (bad wine), i.e. there was either a tendency to leave grapes on the vine for longer or harvest earlier (Anonymous 1908). 


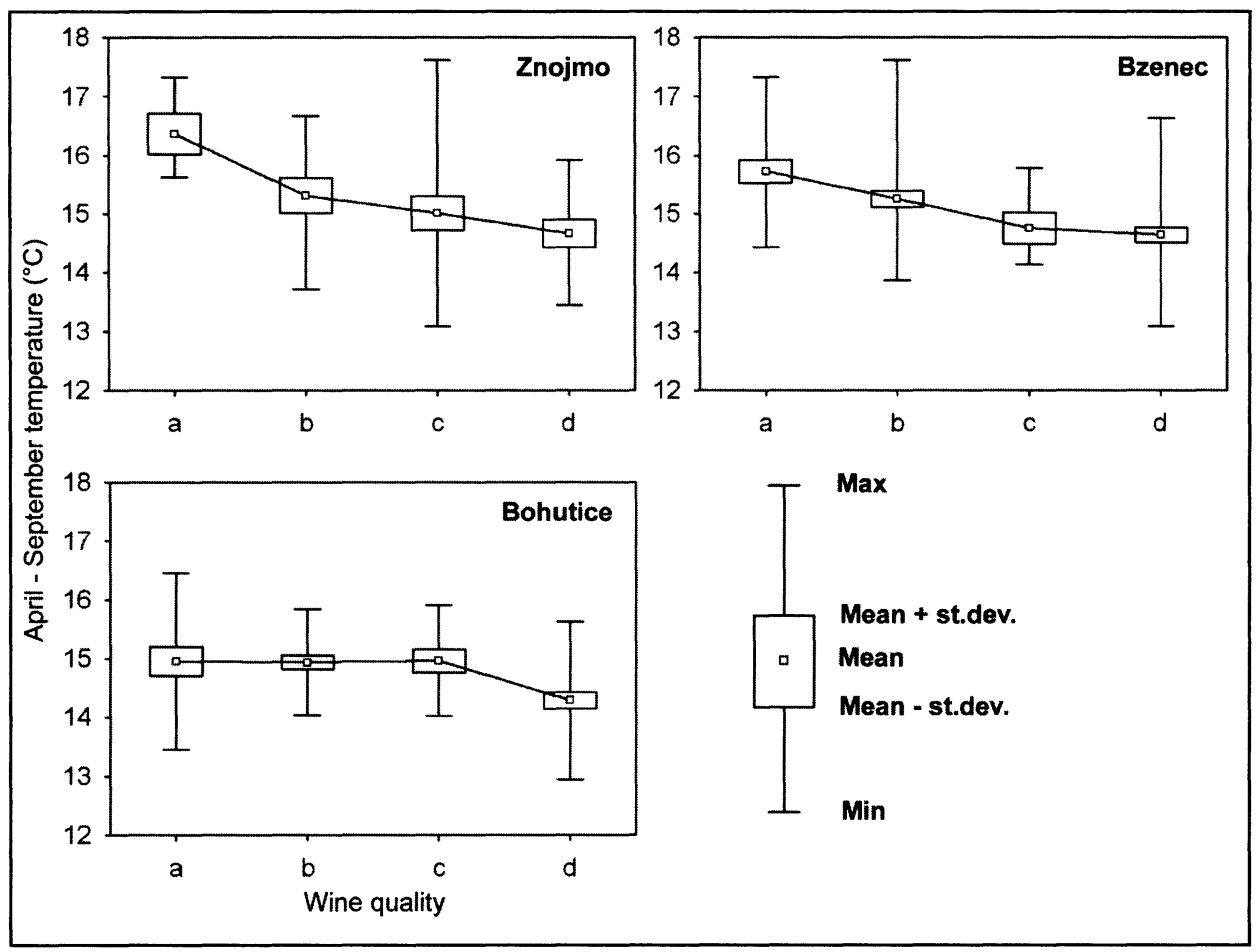

Fig. 5 - Box plot of Brno April-September temperatures calculated for four groups of wine quality in Znojmo (1802-1845), Bzenec (1800-1890) and Bohutice (1861-1912): a excellent, b - good, c - average, d - bad wine (st. dev. - standard deviation).

In addition to vintage dates, it proved possible to use series of wine quality for Znojmo (Haase 1873), divided into four groups: excellent, good, average, bad (sour) wine. A box plot was used to show April-September temperatures in the Brno series for these groups (Fig. 5). As expected, lower quality of wine is a consequence of lower temperatures, i.e. differences in mean April-September temperatures between individual groups should be statistically significant according to t-test for a significance level of $\alpha=0.05$. The only differences between temperature means for good and average wine, as well as between average and bad wine, were insignificant.

A wine quality series may also be compiled for Bzenec, where supervisor (horný) Filip Rúbik recorded yields, quality and quantity of wine for 1796-1840. These records were extended to 1849 by Martin Richman (Hanák 1922) and were further prolonged to 1899 (Anonymous 1908). Using the Bzenec data for the period 1800-1890, it was possible to perform the same analysis as for Znojmo (Fig. 5). This shows that differences in mean Brno April-September temperatures were insignificant between neighbour categories (e.g. excellent and good, good and average, average and bad), but significant with step over one category (e.g. excellent and average or bad, good and bad). The low quantity of sour wine in Bzenec for the every year of $1850-1860$ is noteworthy (Anonymous 1908).

Another wine quality series occurs in the financial records kept by a farmer Josef Svoboda for 1861-1912 in Bohutice (Anonymous 1913). Surprisingly, there is no difference in mean August-September temperatures to correspond 
Table 2 - Correlation coefficients of mean monthly temperatures with vintage of various grape varieties in Velké Pavlovice during the period 1984-2007 (missing years: Modrý Portugal - 1985, 1987, 1991; Veltlínské zelené - 1987, 1989, 1991; Frankovka - 1987, 1988, $1991,1997)$. Statistically significant coefficients according to the t-test for the $\alpha=0.05$ significance level are shown in bold.

\begin{tabular}{|l|c|c|c|c|c|c|c|}
\hline Grape variety & \multicolumn{7}{|c|}{ Months } \\
\cline { 2 - 8 } & Apr. & May & June & July & Aug. & Sep. & $\begin{array}{c}\text { Apr.- } \\
\text { May }\end{array}$ \\
\hline Modrý Portugal & $\mathbf{- 0 . 4 7}$ & $\mathbf{- 0 . 7 7}$ & $-\mathbf{0 . 6 6}$ & -0.18 & -0.41 & -0.09 & $-\mathbf{0 . 7 9}$ \\
Veltlínské zelené & -0.43 & $\mathbf{- 0 . 5 4}$ & -0.40 & -0.11 & -0.40 & -0.07 & $\mathbf{- 0 . 6 1}$ \\
Frankovka & -0.45 & $\mathbf{- 0 . 6 9}$ & -0.44 & -0.01 & -0.34 & -0.06 & $\mathbf{- 0 . 7 2}$ \\
\hline
\end{tabular}

\begin{tabular}{|l|c|c|c|c|c|c|c|}
\hline \multirow{2}{*}{ Grape variety } & \multicolumn{9}{|c|}{ Months } \\
\cline { 2 - 8 } & $\begin{array}{c}\text { May- } \\
\text { June }\end{array}$ & $\begin{array}{c}\text { June- } \\
\text { July }\end{array}$ & $\begin{array}{c}\text { July- } \\
\text { Aug. }\end{array}$ & $\begin{array}{c}\text { Aug.- } \\
\text { Sep. }\end{array}$ & $\begin{array}{c}\text { Apr.- } \\
\text { June }\end{array}$ & $\begin{array}{c}\text { May- } \\
\text { July }\end{array}$ & $\begin{array}{c}\text { June- } \\
\text { Aug. }\end{array}$ \\
\hline Modrý Portugal & $\mathbf{- 0 . 8 1}$ & $\mathbf{- 0 . 4 9}$ & -0.39 & -0.36 & $\mathbf{- 0 . 8 1}$ & $\mathbf{- 0 . 7 2}$ & $-\mathbf{0 . 5 5}$ \\
Veltlínské zelené & $\mathbf{- 0 . 5 3}$ & -0.30 & -0.33 & -0.33 & $\mathbf{- 0 . 5 6}$ & -0.47 & -0.40 \\
Frankovka & $\mathbf{- 0 . 6 3}$ & -0.25 & -0.22 & -0.29 & $\mathbf{- 0 . 6 8}$ & $\mathbf{- 0 . 4 9}$ & -0.34 \\
\hline
\end{tabular}

\begin{tabular}{|l|c|c|c|c|c|c|c|}
\hline \multirow{2}{*}{ Grape variety } & \multicolumn{7}{|c|}{ Months } \\
\cline { 2 - 8 } & $\begin{array}{c}\text { July- } \\
\text { Sep. }\end{array}$ & $\begin{array}{c}\text { Apr.- } \\
\text { July }\end{array}$ & $\begin{array}{c}\text { May- } \\
\text { Aug. }\end{array}$ & $\begin{array}{c}\text { June- } \\
\text { Sep. }\end{array}$ & $\begin{array}{c}\text { Apr.- } \\
\text { Aug. }\end{array}$ & $\begin{array}{c}\text { May- } \\
\text { Sep. }\end{array}$ & $\begin{array}{c}\text { Apr.- } \\
\text { Sep. }\end{array}$ \\
\hline Modrý Portugal & -0.32 & $\mathbf{- 0 . 7 8}$ & $\mathbf{- 0 . 7 2}$ & $\mathbf{- 0 . 4 8}$ & $\mathbf{- 0 . 7 9}$ & $\mathbf{- 0 . 6 5}$ & $\mathbf{- 0 . 7 2}$ \\
Veltlínské zelené & -0.26 & $\mathbf{- 0 . 5 5}$ & $\mathbf{- 0 . 5 2}$ & -0.35 & $\mathbf{- 0 . 5 8}$ & -0.47 & $\mathbf{- 0 . 5 4}$ \\
Frankovka & -0.19 & $\mathbf{- 0 . 5 8}$ & $\mathbf{- 0 . 5 1}$ & -0.30 & $\mathbf{- 0 . 6 1}$ & -0.46 & $\mathbf{- 0 . 5 4}$ \\
\hline
\end{tabular}

with excellent, good or average wine. On the other hand, all three categories differ from sour wine to a statistically significant degree (Fig. 5).

Viticulture in the 19th century was also, of course, negatively affected by weather extremes. For example, as reported for Bzenec, in 1814 the majority of vineyards were frozen by spring frosts and everything that survived was frozen in August. For 1820, the record says "all vineyards frozen to tobacco and there was no wine". Further, frost damage in Bzenec was also mentioned for 1821 and 1823-1825. In 1825, as well as spring frosts, hail occurred three times, so bad that "it was not possible to recognise where the vineyards were". On the other hand, in 1834 grapes were already being harvested on 20 September and "the wine was so good that nobody remembered having wine of such unheard virtue: it was strong, sweet and clean" (Hanák 1922).

\section{Phenology of the vine and recent warming: Velké Pavlovice 1956-2007}

Phenological yearbooks published since 1923 contain no information about viticulture (e.g. Fenologická ročenka 1953-1963). This means that the relationships between vine phenophases and temperatures for a couple of decades may be studied only for the few stations preserved in the archives of the Czech Hydrometeorological Institute. Changes in observation practice may be another complication in obtaining such long series. The basic 
instructions for observers were laid down in 1956 (Pifflová et al. 1956) and include the following observed variables for the vine Vinis vinifera: start of pruning, emergence of buds and blossom, general flowering, general yellowing of leaves, and full maturity (beginning of vintage). This was replaced by new guidelines in 1984 (Valter 1981).

Looking at changes in these instructions and the type of data in documentary sources, it was possible to use only series for the beginning of blossoming and the harvest for the Frankovka (Lemberger) grape in Velké Pavlovice for 1956-2007. The monthly temperatures at the climatological station were first checked for relative homogeneity by Standard Normal Homogeneity Test (Alexandersson 1986) and then adjusted with respect to the non-homogeneity year of 1975. The start of blossoming correlates best with April-June temperatures (-0.79). Much weaker, but still statistically significant, are correlations of vintage with temperatures combined for different months (May -0.46, May-June -0.45, March-June and April-June -0.44 , etc.; Fig. 6 ).

Correlations comparable with the Frankovka variety may be found for the Veltlínské zelené (Grüner Veltliner) variety and much better correlations for the Modrý Portugal (Blauer Portugieser) variety in the common period 1984-2007 (Table 2). This demonstrates differences in the sensitivity of individual grape varieties to temperature patterns in the vegetation period (Kraus 1964, 1999). The Modrý Portugal variety needs a sum of temperatures
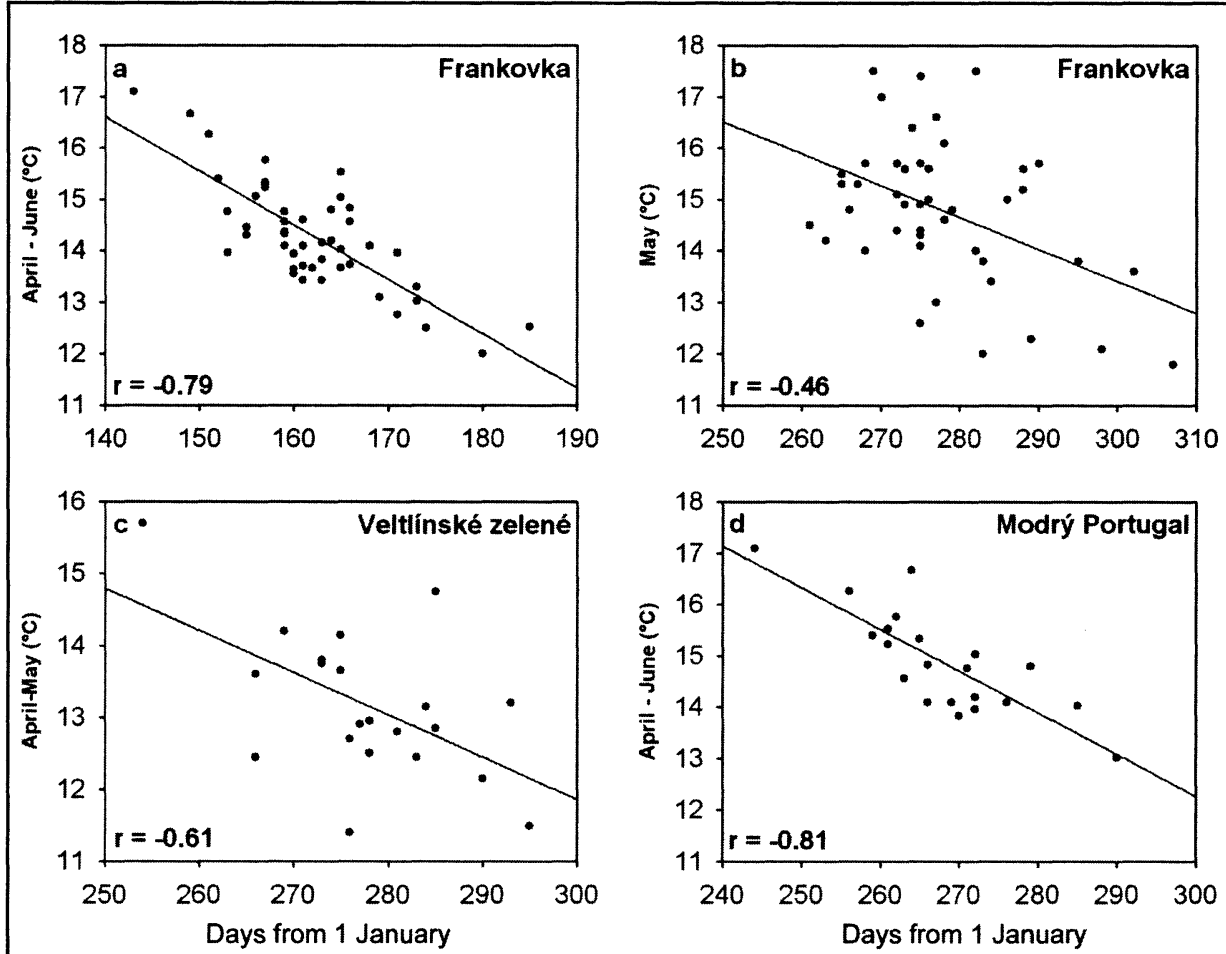

Fig. 6 - Correlations between temperatures and grapevine phenophases for various grape varieties at Velké Pavlovice: a) beginning of flowering, b) beginning of vintage - both 1956-2007, c) and d) beginning of vintage, 1984-2007; r - correlation coefficient. 
$\geq 10^{\circ} \mathrm{C}$ in the vegetation period of between 2,000 and $2,250^{\circ} \mathrm{C}$ for maturation. These values are reached early, and the beginning of vintage depends on the time at which they are achieved. On the other hand, the Vetlinské zelené and particularly Frankovka varieties need temperature sums between 2,500 and $2,750^{\circ} \mathrm{C}$; they ripen later and can even be left longer in the vineyard for improvement of grape quality before harvesting. This means that changes in vintage beginnings are even more dispersed, sensitive to viticultural practices, and less directly related to temperatures.

\section{Discussion and conclusions}

Until the second part of the 19th century, viticulture was an essential source of livelihood for people in many settlements. For example, the village of Kurdějov turned to Empress Maria Theresa in 1766 with a request that its grain debt be relieved (Nosek 1908). The lord of the Pavlovice demesne had lent the grain in 1762, and the village intended to repay the debt from the abundant grape harvest of that year. However, this offer was twice refused. It emerged in the following part of the request that three barren wine years, $1763-1765$, followed and in 1766 the vines were sorely afflicted by hail and grape mildew (Peronospora spp.), to the extent that the estimated damage amounted to thousands of gulden. Based on these facts, postponement of debt instalments or their cancellation was requested (Nosek 1908). Another example of the importance of viticulture is related to heavy frost damage from 10 to 15 May 1831, in which vineyards froze in Bavory, Dolní Věstonice and Pouzdrrany. These settlements turned to the regional office in Brno with a request for tax reduction. Although they acknowledged that frost damage per se did not give them right to tax relief, they based their request on the basic importance of viticulture to the villages in the Mikulov area (Brázdil et al. 2003).

Failure of vine cultivation was not confined to individual places. Landsteiner (1999) demonstrated a sudden failure in wine production in Central Europe from the second half of the $1580 \mathrm{~s}$ to the end of the 16th century. Series of bad grape harvests started in Switzerland in 1585, continued in 1586 in Württemberg and in 1587 affected Lower Austria and western Hungary. Lower wine production was followed by a definite reduction of viticulture income to the Habsburg state treasury. Moreover, higher wine prices and lower sweetness of the product led the public in Lower Austria to switch from wine to beer consumption. This data correlates well with information from Litoměřice and Židlochovice, where only small quantities of wine were recorded in 1585-1589 and 1591-1594, as well as explicitly sour wine in 1587, 1588, 1591, 1592, 1594 and 1597. In contrast, excellent wine was mentioned only in 1590, good wine in 1586 and 1599. Abundant yields occurred in 1586, 1590 and 1596 , while in 1595 and 1597 the yield of grapes was characterised as average (Brázdil, Kotyza 2002).

All of this is summed up well by Hanák (1919), referring to the evaluation of historical yields and wine quality in Bzenec: "From records it follows that there are rather few years with excellent wine. For this reason, caution and patience should be prominent [virtues] for every wine merchant; caution (enough) to keep a good wine long enough, so that in the favourable year he will be able to fill barrels with good vintage, and the patience not to be fainthearted in years of bad harvest and not to neglect vineyards, or even to 


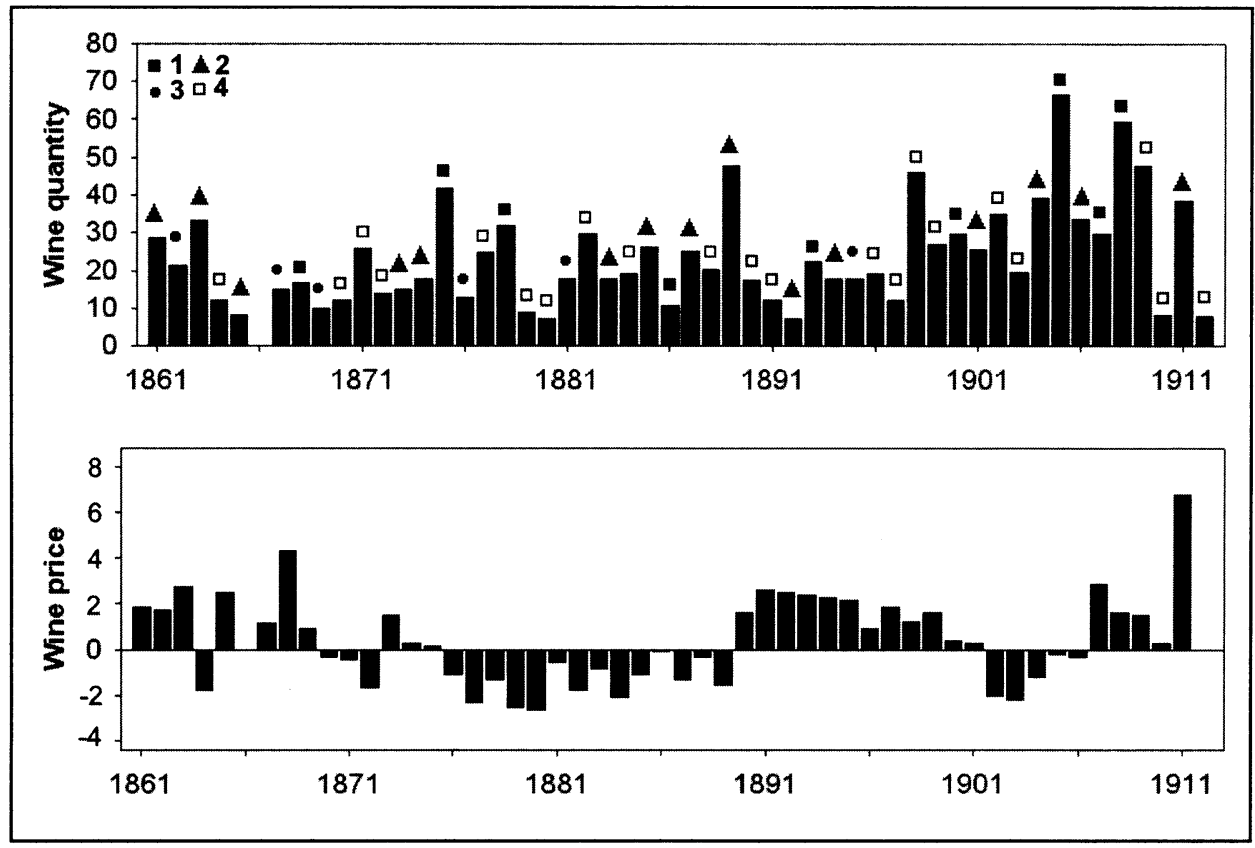

Fig. 7 - Fluctuation of detrended wine prices (gulden) at Bohutice for 1861-1912 (below) in comparison with wine quantity (hl) and quality: 1 - excellent, 2 - good, 3 - average, 4 - bad (above).

abandon them, but wait, since a favourable year will come which will compensate him for the costs of bad years."

Socio-economic factors do not stand alone; weather extremes, quantity and quality of wine were also reflected in the prices of wine, as documented for Bohutice in 1861-1912 (Fig. 7). To avoid inflation, prices were expressed as deviations from the corresponding linear trend. The highest positive deviations (expensive wine) were recorded in 1911 (probably also a consequence of the previous year, when frozen vines as well as cold and rainy weather occurred at blossoming time and the grapes were infected with mould) and in 1868 (bad harvest in the previous three years). Also interesting is a sudden jump from relatively cheap wine in 1876-1889 to more expensive wine in 1890-1901. No wine was available in 1866 due to May frosts, and in 1912 due to hail and mould. An even more important failure of vineyards started in 1866, when heavy frosts in this and following years destroyed many vineyards located at lower elevations. Another negative factor for viticulture might be related to the occurrence of phylloxera disease, which first appeared in 1872 in Austria and started to spread to further parts of the AustrianHungarian empire. As a consequence of this development, farmers around Znojmo and along the Dyje River eventually turned to the cultivation of cucumbers and other vegetables (Anonymous 1923).

It follows from this article that much data related to viticulture containing direct or proxy information about the weather and meteorological extremes exists in the Czech Republic. However, a great deal of this information is of a fragmentary character from the temporal and spatial points of view. The possibility that these gaps may be filled in the course of further archive 
research remains open. Such fragmentation provides a reason for the relative unavailability of continuous series of climate-relevant viticultural data for selected places (e.g. beginnings of grape harvest) that might be used for temperature reconstruction in the Czech Republic, with no chance of following the quantitative temperature reconstructions known from other countries (e.g. Chuine et al. 2004; Meier et al. 2007). The best viticulture data for the 19th century appears somewhat unpromising for temperature reconstructions since several long-term instrumental temperature series already exist. On the other hand, data on the impacts of weather extremes on grape production are already significantly completing and verifying the chronologies of extreme events available in the historical-climatological database of the Institute of Geography, Masaryk University, Brno, and may also be used in research into historical viticulture.

Acknowledgements: We would like to thank RNDr. Jiř́ Nekovář (CHMI Prague) for providing us with phenological vine data from the Velké Pavlovice station, and Tony Long (Svinošice) for English style corrections. Particular thanks must be extended to This Rutishauer (Bern) and the second anonymous reviewer for valuable criticism and comments.

\section{References:}

ADAM Z VELESLAVÍNA, D. (1590): Kalendář Historický. To jest krátké poznamenání všech dnuov jednoho každého měsíce přes celý rok. $\mathrm{K}$ nim přidány jsou některé paměti hodné Historiae o rozličných př́íhodách a proměnách, jak národuov jiných a zemí v Světě, tak také a obzvláštně národu i Království Českého z hodnověrných Kronik. Staré Město Pražské.

ALEXANDERSSON, H. (1986): A homogeneity test applied to precipitation data. Journal of Climatology, 6, No. 6, pp. 661-675.

ANONYMOUS (1908): Bzenecké víno od roku 1796 až 1908. Vinařský obzor, 2, No. 7, pp. 244-249.

ANONYMOUS (1913): Sklizeň vína od r. 1861-1912. Vinařský obzor, 7, No. 7, pp. 137-140.

ANONYMOUS (1923): Jihomoravské vinařství. Vinařský obzor, 17, No. 8, pp. 72-73.

BRÁZDIL, R., DOBRÝ, J., KYNCL, J., ŠTĚPÁNKOVÂ, P. (1997): Rekonstrukce teploty vzduchu teplého pủlroku $\mathbf{v}$ oblasti Krkonoš na základě letokruhů smrku v období 1804-1989. Geografie-Sborník ČGS, 102, No. 1, pp. 3-16.

BRÁZDIL, R., KOTYZA, O. (1995): History of Weather and Climate in the Czech Lands I (Period 1000-1500). Zürcher Geographische Schriften, No. 62, Zürich, 260 pp.

BRÁZDIL, R., KOTYZA, O. (2000): History of Weather and Climate in the Czech Lands IV. Utilisation of economic sources for the study of climate fluctuation in the Louny region in the fifteenth-seventeenth centuries. Masaryk University, Brno, $350 \mathrm{pp}$.

BRÁZDIL, R., KOTYZA, O. (2002): Současná historická klimatologie a možnosti jejího využití v historickém výzkumu. Časopis Matice moravské 120/2001/Supplementum, pp. 17-59.

BRAZDIL, R., PFISTER, C., WANNER, H., VON STORCH, H., LUTERBACHER, J. (2005a): Historical climatology in Europe - the state of the art. Climatic Change, 70, No. 3, pp. 363-430.

BRÁZDIL, R., VALÁŠEK, H. (2005): Historické informace o pěstování vinné révy jako zdroj údajů pro historickou klimatologii. (Úvod do problematiky.). In: Dějiny vinařství na Moravě. Sborník př́ispěvků z konference, Brno, pp. 17-26.

BRÁZDIL, R., VALAŚEK, H., KOTYZA, O. (2004): Meteorological records of Michel Stüeler of Krupka and their contribution to the knowledge of the climate of the Czech Lands in 1629-1649. In: Drbohlav, D., Kalvoda, J., Voženílek, V. (eds.): Czech Geography at the Dawn of the Millenium. Palacky University, Olomouc, pp. 95-112.

BRÁZDIL, R., VALÁŠEK, H., MACKOVÁ, J. (2005b): Meteorologická pozorování v Brně v první polovině 19. století (Historie počasí a hydrometeorologických extrémů). Archiv 
města Brna, Brno, 450 pp.

BRÁZDIL, R., VALÁŚEK, H., SVITÁK, Z. (2003): Meteorological and hydrological extremes in the Dietrichstein domains of Dolní Kounice and Mikulov between 1650 and 1849 according to official economic records of natural disasters. Geografický časopis, 55, No. 4, pp. 325-353.

BURKHARDT, T., HENSE, A. (1985): On the reconstruction of temperature records from proxy data in Mid Europe. Archives for Meteorology, Geophysics and Bioclimatology - Series B 35, pp. 341-359.

Chronicon magistri Georgii Pisensis. Ed. Fontes Rerum Bohemicarum - Prameny dějin českých VI, Praha 1907, pp. 355-362.

CHUINE, I., YIOU, P., VIOVY, N., SEGUIN, B., DAUX, V., LE ROY LADURIE, E. (2004): Historical phenology: Grape ripening as a past climate indicator. Nature, 432 , No. 7015, pp. 289-290.

COOK, E. R., BRIFFA, K. R., JONES, P. D. (1994): Spatial regression methods in dendroclimatology: A review and comparison of two techniques. International Journal of Climatology, 14, No. 4, pp. 379-402.

DONEK, E., PŠTROSS, B., ČEBIŠ, F. R. (1932): O litoměřickém víně. Soukromý tisk Jos. Oppelta synovce, Praha, $42 \mathrm{pp}$.

DVORSKÝ, F., ed. (1888): Dopisy pana Zdeňka Lva z Rožmitálu z let 1508-1535. In: Kalousek, J. (ed.): Archiv český čili staré písemné památky české i moravské, sebrané z archivů domácích i cizích. Díl VIII. Nákladem Domestikálního fondu Království českého, Praha, pp. 61-320.

Fenologická ročenka Československé republiky 1938-1955. Hydrometeorologický ústav, Praha 1953-1963.

FROLEC, V., KRAUS, V., POŠVÁř, J., PUBAL, V., VÁVRA, M., VERMOUZEK, R., ZEMEK, M., VIGNATIOVÁ, J., ZIMÁKOVÁ, A. (1973): Vinohradnictví. Kapitoly z dějinného vývoje od minulosti do současnosti na Moravě a v Cechách. Blok, Brno, $300 \mathrm{pp}$.

GLASER, R. (1991): Klimarekonstruktion für Mainfranken, Bauland und Odenwald anhand direkter und indirekter Witterungsdaten seit 1500. Gustav Fischer Verlag, Stuttgart, New York, 175 pp.

GLASER, R., BRÁZDIL, R., PFISTER, C., DOBROVOLNÝ, P., BARRIENDOS VALLVÉ, M., BOKWA, A., CAMUFFO, D., KOTYZA, O., LIMANÓWKA, D., RÁCZ, L., RODRIGO, F. S. (1999): Seasonal temperature and precipitation fluctuations in selected parts of Europe during the sixteenth century. Climatic Change, 43, No. 1, pp. 169-200.

HAASE, J. (1873): Weinbau in Znaimer und Joslowitzer Gerichtsbezirke in Mähren. Im Selbstverlage des Verfasser, Znaim, $60 \mathrm{pp}$.

HANÁK, J. (1919): Paměti města Bzence. Nákladem města Bzence, Bzenec, 166 pp.

HANÁK, J. (1922): Dějiny vinařství v Bzenci. Kulturně-historický nákres. Slovácká knihtiskárna K. Novotného, Uherské Hradiště, 73 pp.

HLAVINKA, K. (1908): Moravské víno a obilí od r. 1704-1744. Selský archiv, 7, No. 2(26), pp. 38-44.

KATZEROWSKY, W. (1887): Die meteorologischen Aufzeichnungen des Leitmeritzer Rathsverwandten Anton Gottfried Schmidt aus den Jahren 1500 bis 1761. Ein Beitrag zur Meteorologie Böhmens. Im Selbstverlag, Prag, 29 pp.

KEENAN, D. J. (2007): Grape harvest dates are poor indicators of summer warmth. Theoretical and Applied Climatology, 87, No. 1-4, pp. 255-256.

KOŠŤÁL, M. (1958): O významu severočeského vinařství v minulosti. Sborník Československé akademie zemědělských věd - Historie a muzejnictví 3 (31), No. 3 , pp. 173-202.

KRAUS, V. (1964): Příspěvek k poznání přírodních vlivů určujících jakost žernoseckých vín. Vlastivědný sborník Litoměřicko, No. 1-2, pp. 33-36.

KRAUS, V. (1999): Réva vinná v Čechách a na Moravě. Radex, Praha, 280 pp.

LANDSTEINER, E. (1999): The crisis of wine production in late sixteenth-century central Europe: Climatic causes and economic consequences. Climatic Change, 43, No. 1, pp. $323-334$.

LAUER, W., FRANKENBERG, P. (1986): Zur Rekonstruktion des Klimas im Bereich der Rheinpfalz seit Mitte des 16. Jahrhundert mit Hilfe von Zeitreihen der Weinquantität und Weinqualität. Gustav Fischer Verlag, Stuttgart, New York, 54 pp.

LAUSCHER, F. (1983): Weinlese in Frankreich und Jahrestemperatur in Paris seit 1452. Wetter und Leben, 35, No. 1, pp. 39-42. 
LAUSCHER, F. (1985): Beiträge zur Wetterchronik seit dem Mittelalter. In: Sitzungsberichte der mathem.-naturw. Klasse - Abtheilung II, 194, pp. 93-131.

LECHNER, K. (1896): Zur Geschichte der Preise. Notizenblatt des Vereines für die Geschichte Mährens und Schlesiens, No. 9-10, pp. 151-152.

LE ROY LADURIE, E. (2004): Histoire humaine et comparée du climat: Canicules et glaciers XIII ${ }^{\mathrm{e}}-\mathrm{XVIII}{ }^{\mathrm{e}}$ siècles. Fayard, Paris, $744 \mathrm{pp}$.

LE ROY LADURIE, E. (2006): Histoire humaine et comparée du climat: Disettes et révolutions 1740-1860. Fayard, Paris, $616 \mathrm{pp}$.

LE ROY LADURIE, E. (2007): Abrégé d'historie du climat du Moyen Âge à nos jours. Fayard, Paris, $178 \mathrm{pp}$.

LE ROY LADURIE, E., BAULANT, M. (1980): Grape harvests from the fifteenth through the nineteenth centuries. Journal of Interdisciplinary History, 10, No. 4, pp. 839-849.

MEIER, N., RUTISHAUSER, T., PFISTER, C., WANNER, H., LUTERBACHER, J. (2007): Grape harvest dates as a proxy for Swiss April to August temperature reconstructions back to AD 1480. Geophysical Research Letters, 34, L20705.

MENZEL, A. (2005): A 500-year pheno-climatological view on the 2003 heatwave in Europe assessed by grape harvest dates. Meteorologische Zeitschrift, 14, No. 1, pp. 75-77.

MIHÁLIKOVÁ, I. (1983): 60 let fenologické staniční sítě. Meteorologické zprávy, 36, No. 6, pp. 187-188.

MULLINS, M. (1992): Biology of the Grapevine. Cambridge University Press, Cambridge, $239 \mathrm{pp}$.

NEKOVǍr, J. (2008): The history and current status of Czech plant phenology. In: COST Action 725 - The history and current status of plant phenology in Europe. COST Office, Brussels, pp. 51-57.

NOSEK, F. (1908): Z bídných let v Kurdějově. 1762-1768. Selský archiv, 7, No. 3(27), pp. 117-118.

ONDRŮJ, A. (1977): Dokument ze života na žerotínské tvrzi v Židlochovicích na přelomu 16. a 17. století. Jižní Morava, 13, pp. 168-177.

PEJML, K. (1974): Př́íspěvek ke znalosti kolísání klimatu v Čechách v 16. až 18. stol. Meteorologické zprávy, 27, No. 3, pp. 90-95.

PFISTER, C. (1981): Die Fluktuationen der Weinmosterträge im Schweizerischen Weinland vom 16. bis ins frühe 19. Jahrhundert. Klimatische Ursachen und sozioökonomische Bedeutung. Schweizer Zeitschrift für Geschichte, 31, No. 4, pp. 445-491.

PFISTER, C. (1988): Variations in the spring-summer climate of central Europe from the High Middle Ages to 1850. In: Wanner, H., Siegenthaler, U. (eds.): Long and Short Term Variability of Climate. Springer-Verlag, Berlin, Heidelberg, New York, London, Paris, Tokyo, pp. 57-82.

PFISTER, C., BRÁZDIL, R. (1999): Climatic variability in sixteenth-century Europe and its social dimension: A synthesis. Climatic Change, 43, No. 1, pp. 5-53.

PIFFLOVÁ, L., BRABLEC, J., LENNER, V., MINÁŘ, M. (1956): Přríručka pro fenologické pozorovatele. Hydrometeorologický ústav, Praha, $168 \mathrm{pp}$.

PÍSEK, J., BRÁZDIL, R. (2006): Responses of large volcanic eruptions in the instrumental and documentary climatic data over Central Europe. International Journal of Climatology, 26, No. 4, pp. 439-459.

SOURIAU, A., YIOU, P. (2001): Grape harvest dates for checking NAO paleoreconstructions. Geophysical Research Letters, 28, pp. 3895-3898.

STRÖMMER, E. (2003): Klima-Geschichte. Methoden der Rekonstruktion und historische Perspektive. Ostösterreich 1700 bis 1830 . Franz Deuticke, Wien, 325 pp.

STŘEŚTÍK, J., VERÖ, J. (2000): Reconstruction of the spring temperatures in the 18th century based on the measured lengths of grapevine sprout. Időjárás, 104, No. 2, pp. 123-136.

ŠTEPPÁNEK, P., ŘEZNÍČKOVÁ, L., BRÁZDIL, R. (2006): Homogenization of daily air pressure and temperature series for Brno (Czech Republic) in the period 1848-2005. In: Proceedings of the Fifth Seminar for Homogenization and Quality Control in Climatological Databases, Budapest, pp. 98-115.

TEPLÝ, F. (1902): Krátké poznamenání hodnověrných pamětných věcí král. věnného města Melníka nad Labem, tj. Notatia Historica reg. dotalis Civitatis Melnicensis ad Albim. Sepsáno od Jana Josefa Albrechta, tehdejšího písaře radního v témž král. věnném městě, neméně přísežního procuratora při vyššíh Instanciích v království Českém leta Páně 1771 dne 2. června. Sborník Historického kroužku, 3, No. 2, pp. 115-119, No. 3, pp. 149-154, No. 4, pp. 219-224. 
VALTER, J. (1981): Návod pro činnost fenologických stanic. Metodický předpis č. 3. Český hydrometeorologický ústav, Praha, $148 \mathrm{pp}$.

VANIŠ, J. (1979): Liber rationum regalis civitatis Lunae ad annos 1450-1472 et 1490-1491 pertinens. Academia, Praha, 968 pp.

WELZL, H. (1910): Brünner Chronik des Peter Freiherrn v. Forgatsch. Zeitschrift des Deutschen Vereines für die Geschichte Mährens und Schlesiens, 14, pp. 265-308.

WINKLER, A., COOK, J., KLIEWERE, W., LIDER, L. (1974): General Viticulture. University of California Press, London, $740 \mathrm{pp}$.

\section{Archival sources:}

Kniha pamětní litoměřických městských písařů 1570-1607. SOkA Litoměřice, fond AM Litoměřice, sign. IV B 1a.

KNOTT, R. (s.a.): Michel Stüelers Gedenkbuch. SOkA Teplice, fond AM Krupka, dodatky inv. č. 1.

Kronika Hustopečí (Consignation oder Inschreibung unterschiedlicher Denkwürdigkeiten, welche sich bey dieser Hochfürstlichen Lichtensteinischen Stadt Auspitz vermög nachfolgenden Annalibus und Datis zu unterschiedenen materio zugetragen wie solche hernach folgen). MZA Brno, fond E6 Benediktini Rajhrad, Hb27.

Vinobranní, vinice a víno. SOkA Znojmo, fond Katalog staré spisovny města Znojma, inv. č. XVIII.1, karton 404.

\section{Shrnutí}

\section{VINAŘSTVÍ V MINULOSTI A V SOUČASNOSTI JAKO ZDROJ KLIMATOLOGICKÝCH POZNATKƯ V ČESKÉ REPUBLICE}

Pěstování vinné révy (Vinis vinifera) a vinařství v České republice je významně ovlivněno počasím. Závislost na počasí umožňuje využít informace o pěstování vinné révy (např. začátek vinobraní, množství a kvalita vína) jako nepřímý indikátor pro rekonstrukci teploty vzduchu a výskytu povětrnostních extrémů $\mathrm{v}$ minulosti. Tato studie shrnuje základní poznatky o vztazích mezi vinařstvím a klimatem v českých zemích pro oblast Čech (zejména Lounsko a Litoměřicko) a jižní Moravy během několika posledních století opírajíce se o různé typy dokumentárních pramenů (kroniky, paměti, deníkové záznamy, osobní a oficiální korespondence, noviny, záznamy ekonomické povahy, odborné práce). Zatímco před rokem 1500 jsou informace tohoto typu spíše sporadické v závislosti na dochovaných pramenech, pro 16.-18. století již bylo možné stanovit dekádové četnosti výskytu povětrnostních extrémů se škodami na vinné révě (pozdní jarní a časné podzimní mrazy, krupobití), kvality vína (špatné, průměrné, dobré, výborné) a množství vína (málo nebo žádné, průměrně, nadbytek) ve vinařských oblastech Čech a jižní Moravy (obr. 3). V řadě roků během těchto tří století však jakékoliv informace o pěstování vinné révy chybí úplně. Data začátků vinobraní ze Znojma, získaná z protokolů městské rady nebo oznámení v novinách Znaimer Wochenblatt pro období 1800-1890 byla využita pro rekonstrukci teplot vzduchu dubna-srpna v Brně s použitím lineárního regresního modelu (obr. 4). Parametry rekonstrukce (tab. 1) sice ukazují na využitelný potenciál této metody pro teplotní rekonstrukce, dostupné řady počátků vinobraní pro období před začátkem systematických teplotních měření v českých zemích jsou však zatím spíše sporadické. Pro Bzenec (1800-1890), Znojmo (1802-1845) a Bohutice (1861-1912) byly použity rady kvality vína (výborné, dobré, průměrné, špatné či kyselé) $\mathrm{k}$ vyjádření jejich závislosti na teplotě vzduchu (obr. 5). Zatímco v případě Bzence a Znojma bylo možné prokázat statisticky významné rozdíly mezi průměrnými teplotami odpovídajícími jednotlivým kategoriím kvality vína, pro Bohutice se takto lišily pouze první tři kategorie od špatného či kyselého vína. Začátek květu vinné révy a vinobraní v závislosti na teplotě vzduchu je analyzován pro Frankovku, Veltlínské zelené a Modrý Portugal podle fenologických pozorování ve Velkých Pavlovicích pro období 1956-2007, resp. 1984-2007, na bázi průměrných měsíčních teplot (obr. 6). U teplotně náročnějších odrůd vinné révy jako je Veltlínské zelené a Frankovka je vazba začátku vinobraní na teplotě vzduchu předchozích měsíců podstatně slabší než u méně náročné odrůdy Modrý Portugal (tab. 2). Pro Bohutice je demonstrováno kolísání cen vína v letech 1861-1912 v porovnání s množstvím vína a jeho kvalitou (obr. 7). 
Obr. 1 - Místa v České republice zmiňovaná v textu: 1 - Bavory, 2 - Bohutice, 3 - Bratčice, 4 - Bzenec, 5 - Cejkovice, 6 - Dolní Kounice, 7 - Dolní Věstonice, 8 - Drnholec, 9 - Hustopeče, 10 - Kamýk, 11 - Klentnice, 12 - Krupka, 13 - Kuchařovice, 14 - Kurdějov, 15 - Litoměřice, 16 - Louny, 17 - Lovosice, 18 - Malíč, 19 - Mělčany, 20 - Mělník, 21 - Mikulov, 22 - Mušov, 23 - Olomouc, 24 - Pavlov, 25 - Perná, 26 - Ploskovice, 27 - Pouzdřany, 28 - Raná, 29 - Syrovice, 30 - Velké Pavlovice, 31 - Velké Žernoseky, 32 - Znojmo, 33 - Židlochovice.

Obr. 2 - Symboly sklizně a lisování vinných hroznů byly použity Johannem Willenbergem pro znázornění měsíce ř́ijna v kalendáři na rok 1604. Vinobraní začínalo $\mathrm{v}$ tomto měsíci nejčastěji na Lounsku stejně jako v jiných místech českých zemí.

Obr. 3 - Dekádové četnosti výskytu povětrnostních extrémů se škodami na vinné révě (1 - pozdní jarní mráz, 2 - časný podzimní mráz, 3 - krupobití), kvality vína (4 - špatná, 5 - průměrná, 6 - dobrá, 7 - výborná) a množství vína (8 - málo nebo žádné, 9 - průměrné, 10 - mnoho) ve vinařských oblastech Čech (a) a jižní Moravy (b) v 16.-18. století.

Obr. 4 - Variabilita začátků vinobraní ve Znojmě (počet dnů od 1. září; nahoře) a porovnání měřených (1) a rekonstruovaných (2) teplot vzduchu dubna-srpna v Brně v podobě anomálií od referenčního období 1961-1990 a míra nejistoty rekonstrukce (šedě) vyjádřená jako 95\% interval spolehlivosti pro každou rekonstruovanou hodnotu v období 1800-1890 (dole).

Obr. 5 - Krabicový graf teplot vzduchu dubna-srpna v Brně počítaných pro čtyři skupiny kvality vína ve Znojmě (1802-1845), Bzenci (1800-1890) a Bohuticích (1861-1912): a - výborná, b - dobrá, c - průměrná, d - špatná.

Obr. 6 - Korelace mezi teplotami vzduchu a fenofázemi vybraných odrůd vinné révy ve Velkých Pavlovicích: a) začátek květu, b) začátek vinobraní - obojí v období 1956-2007, c) a d) začátek vinobraní, 1984-2007; r - korelační koeficient.

Obr. 7 - Kolísání detrendovaných cen vína (zlaté) v Bohuticích v letech 1861-1912 (dole) v porovnání s množstvím vína (hl) a jeho kvalitou: 1 - výborná, 2 - dobrá, 3 - průměrná, 4 - špatná (nahoře).

Tab. 1 - Míry vhodnosti rekonstrukce teplot vzduchu dubna-srpna v Brně. Data o vinobraní ze Znojma jsou použity jako nezávisle proměnná v modelu: $\mathbf{r}^{2}-$ kvadrát korelačního koeficientu, $\mathrm{RE}$ - redukce chyby, CE - koeficient citlivosti, MSE - střední kvadratická chyba.

Tab. 2 - Korelační koeficienty mezi prưměrnými měsíčními teplotami vzduchu a začátky vinobraní pro vybrané odrůdy vinné révy ve Velkých Pavlovicích v období 1984-2007 (chybějící roky: Modrý Portugal - 1985, 1987, 1991; Veltlínské zelené - 1987, 1989, 1991; Frankovka - 1987, 1988, 1991, 1997). Statisticky významné koeficienty podle t-testu na hladině významnosti $\alpha=0.05$ jsou vytištěny tučně.

R. Brázdil, P. Zahradniček and P. Dobrovolný are with Masaryk University, Faculty of Science, Institute of Geography, Kotlářská 2, 61137 Brno; O. Kotyza is with Regional Museum, Mírové nám. 171, 41201 Litoměřce; H. Valášek is with Moravian Land Archives, Palachovo nám. 1, 62500 Brno, Czech Republic; e-mail: brazdil@geogr.muni.cz. 